\title{
Anti herpes simplex virus property of Phyllanthus urinaria (L) as shown by plaque reduction assay
}

Praseno

\begin{abstract}
Abstrak
Obat tradisional telah popular di Indonesia. Banyak di antara obat tersebut yang efektif untuk menyembuhkan pelbagai penyakit, termasuk penyakit infeksi. Berdasarkan hal tersebut, aktifitas anti Herpes Simplex Virus ekstrak Phyllanthus urinaria $(L)$ diteliti secara in vitro dengan metoda "plaque reduction assay". Hasil menunjukkan bahwa ID 100 dicapai oleh ekstrak pada konsentrasi $6 \%$ dan $4 \%$ v/v untuk HSV-2 dan HSV-I
\end{abstract}

\begin{abstract}
Traditional medicine has been popular in Indonesia. Many of them are effective fo curing various diseases. Based on that, antiviral activity to Herpes Simplex Virus of an aqueos phase of extract of Phillantus urinaria (L) plant was investigated in vitro by a plaque reduction assay. Result showed that $\mathrm{ID}_{100}$ was achieved by the extract at concentration of $6 \%$ and $4 \%$ v/v for HSV-2 and HSV-1 respectively.
\end{abstract}

Keywords : Phyllanthus urinaria (L)-Herpes Symplex Virus-traditional medicine-plaque reduction assay

\section{INTRODUCTION}

Indonesian peoples has long been using traditional medication in daily life. Many traditional medicine derived from plants or herbs proved to be effective for curing various diseases, including diabetes, hypertension, renal stone and some infectious diseases.

At last 145 different plants have been documented and reported to have pharmacological properties. ${ }^{1}$ Even with the introduction of modern medicine the practice of using traditional medication is still continuing. Furthermore, several centers for research and development of traditional medicine have been established, such as "Pusat Pengembangan Obat Tradisional" at Gadjah Mada University.

Phyllanthus urinaria (L), or "daun gendong anak" been used effectively for treatment of hepatitis, urinary tract infection, bacilary dysentery, ureteral colic, toothache, and as diuretic. ${ }^{1,2}$ Since the most common cause of hepatitis is viral origin, we predicted that extract of this plants may have antiviral activity. However, because of difficulties in isolation of hepatitis

Department of Microbiology Faculty of Medicine Gadjah Mada University, Yogyakarta, Indonesia viruses or even they cannot be adapted in cell culture system, we used herpes simplex virus to evaluate in vitro antiviral activity of extract of Phyllanthus urinaria $(\mathrm{L})$.

\section{METHODS}

\section{Preparation of the extract}

One gram of whole plant was cut into small pieces and finely ground. This material was transferred into conical tube of $15 \mathrm{ml}$ and added with $9 \mathrm{ml}$ of aquadest and mixed well by brief vortexing. The material was left over night at room temperature to allow water soluble substance to dissolve. On the next day the mixture was spinned down, supernatant collected and filtered through a membrane of $0,45 \mu \mathrm{m}$ pore size. This supernatant containing water soluble extract of the plant is used for the experiment.

\section{Evaluation of antiviral activity by reduction assay method ${ }^{3}$}

Vero cell line was cultured in Dullbeco's Modified Eagle Medium (DMEM) supplemented with $10 \%$ fetal calf serum (FCS) and antibiotic in tissue culture flasks. Culture was incubated at $37^{\circ} \mathrm{C}$ in a humidified incubator with $5 \% \mathrm{CO}_{2}$ atmosphere. After confluent 
monolayer growth was achieved, medium was replaced with $2 \mathrm{ml}$ of fresh DMEM containing 5\% FCS. $0,2 \mathrm{ml}$ suspension of 103 plaque forming unit $/ \mathrm{ml}$ of HSV 1 and HSV 2 were added into individual flaks and the cultures returned into incubator. After 2 hours incubation, flasks were taken out from the incubator and the medium decanted. The culture were rinsed with phophate-buffered saline to remove any remaining virus particles, after which $5 \mathrm{ml}$ of DMEM suplemented with 5\% FCS was added into the flasks. $400 \mu \mathrm{l}, 300 \mu \mathrm{l}, 200 \mu \mathrm{l}, 100 \mu \mathrm{l}, 50 \mu \mathrm{l}$, of the extract were added to individual flasks. Two flasks of culture infected with HSV 1 and HSV 2, respectively were not treated with the extract and served as controls. One flasks of uninfected culture was used as negative control. These prosedures were done in duplicate.

All cultures were reincubated at $37^{\circ} \mathrm{C}$ for three days. At the end of incubation period medium was decanted and the cultures was stained with crystal violet stain to visualised the plaques. Number of plaques on each flasks was compared to that of control.

\section{Interpretation of the result}

Antiviral activity of the extract is expressed of plaque formation and calculated by the formula :

No. of plaque of control - No. of treated culture

No. of plaque of control X $100 \%$
The amount of extract capable of reducing plaque number by $100 \%$ is said to be inhibitory dose $100\left(\mathrm{ID}_{100}\right)$.

\section{RESULT}

Total inhibition of plaque formation (ID100) was achieved by the extract with the concentration of $6 \% \mathrm{v} / \mathrm{v}$ for HSV-2 and $4 \%$ for HSV-1, respectively (table 1).

Concentration of $0,5 \% \mathrm{v} / \mathrm{v}$ has no effect on inhibition of plaque formation on $\mathrm{HSV}-1$ and HSV-2 infected Vero cell was enhanced by addition of the extract. This growth enhancement was clearly seen before and after staining procedure; extract - treated cultures were more deeply stained than those of controls (see figure1).

\section{DISCUSSION}

Our study showed that extract of Phyllanthus urinaria (L) has in vitro activity against Herpes Simplex Virus. Inhibitory Dose 100 was achieved by the extract at concentration of $6 \% \mathrm{v} / \mathrm{v}$ and $4 \% \mathrm{v} / \mathrm{v}$ for HSV-2 and HSV-1, respectively. It means that ID $_{100}$ will be 60 $\mu \mathrm{l} / \mathrm{ml}$ and $40 \mu \mathrm{l} / \mathrm{ml}$. Since we used crude extract in this study, we estimated much lower concentration is required to get ID100 if we used purified extract in the assay.

Table. 1. Inhibitory effect of Phyllanthus urinaria (L) extract on plaque formation of HSV-1 and HSV-2 infected Vero cell line

\begin{tabular}{cccccc}
\hline $\begin{array}{c}\text { Addition of extract } \\
(\mu \mathrm{l})\end{array}$ & $\begin{array}{c}\text { Final concentration } \\
\text { of extract }(\% \mathrm{v} / \mathrm{v})\end{array}$ & $\begin{array}{c}\text { * Number of } \\
\text { Plaque on cultures } \\
\text { infected with }\end{array}$ & $\begin{array}{c}\text { \% inhibition of } \\
\text { plaque formation }\end{array}$ \\
\hline & & HSV-1 & HSV-2 & HSV-1 & HSV-2 \\
\hline 400 & 8 & 0 & 0 & 100 & 100 \\
300 & 6 & 0 & 0 & 100 & 100 \\
200 & 4 & 0 & 36 & 100 & 53,80 \\
100 & 2 & 31 & 42 & 50,70 & 46,14 \\
50 & 1 & 52 & 55 & 17,40 & 29,60 \\
25 & 0,5 & 67 & 82 & 0 & 0 \\
0 & 0 & 63 & 78 & - & - \\
$($ control) & & & & & \\
\hline
\end{tabular}




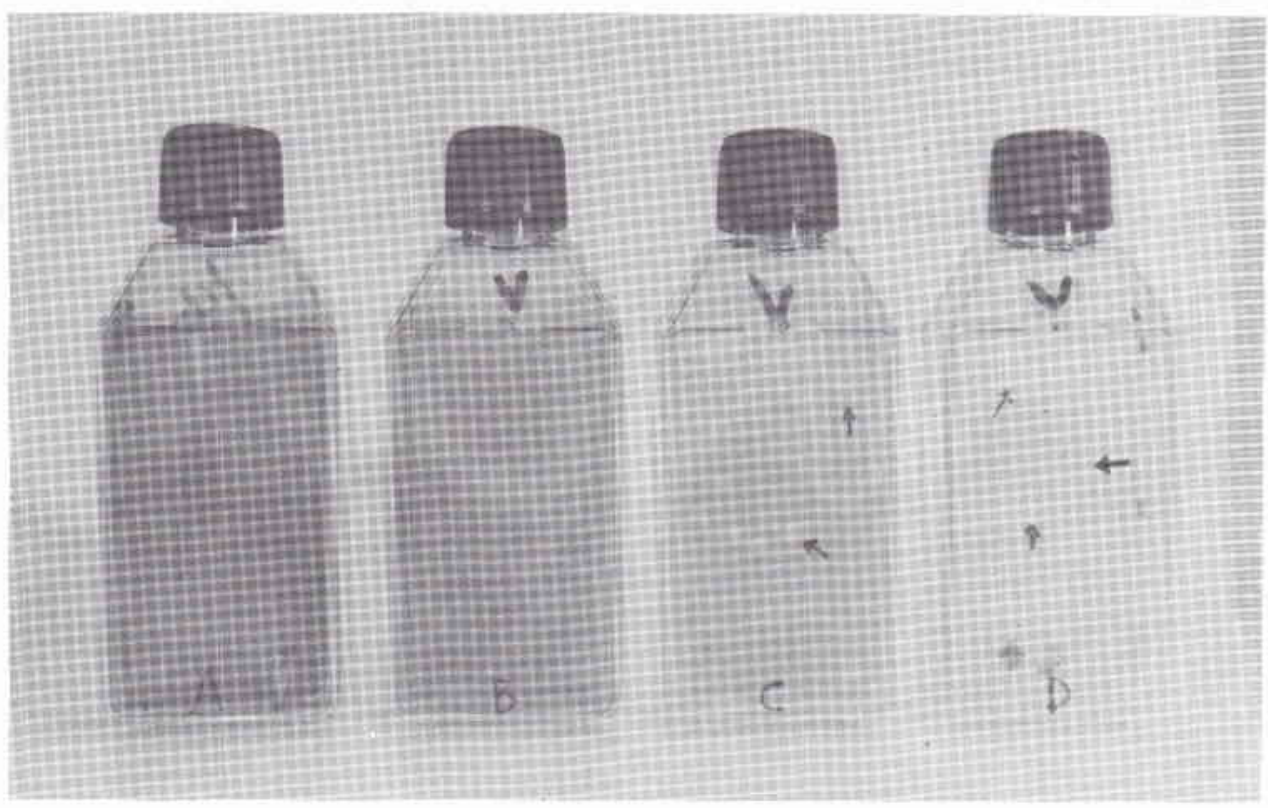

Figure 1. HSV-infected Vero cell line. A, B and C: cultures treated with extract of Phyllanthus urinaria (L). D: untreated culture (control). Arrows indicate positions of the plaques. Note that treated are more densely stained than control.

Enhancement of the growth of Vero cell line in extract treated cultures indicate that there was no toxid effect of this extract on the cell. It is very likely that the extract contains hight concentration of vitamins and minerals which promote growth of the cells.

Specific treatment of HSV infection is usually not required unless serious complication involving visceral organs are anticipated. This is, in part because of relatively expensive commercially available synthetic antiviral drugs for most people in Indonesia. Unfortunately, untreated cases of HSV infection will be potential sources of spreading the virus to other people. In addition, several studies showed that some strains of HSV were resistance to antiviral drugs. ${ }^{4,5}$ The problems were also complicated by the presence of asymtomatic cases who shed the virus persistently and by the ability of the disease to become latent. ${ }^{6,7}$ Despite possible involvement of the brain in HSV infection, especially in immune compromised patients, more attention should be paid to HSV infection during pregnancy as it may cause spontaneous abortion, stillbirth, and congenital malformation or, more frequently, mucocutaneous infection occuring at the time of delivery. ${ }^{8}$

In order to overcome part of these problem, we have been searching back for anti HSV agent derived from plants readily available in our environment. Our previous study showed that another plants, Momordica charantia or spring cucumber, also has in vitro activity against $\mathrm{HSV}-2$. $^{9}$ In vivo activity of these extract are now under investigation. Further studies are also needed to elucidate other pharmacological aspects, including mechanism of action and possible effect of the extract on other viruses. The search for active substance having antiviral effect from these plants is also important. Nevertheless, from practical point of view, it will be more beneficial if the whole plant or the crude extract can be used as an alternative of anti HSV agents as it will much facilitate its use in treatment of HSV infection.

\section{Acknowledgement}

We thank Dr. Nobert Ryan of Fairfield Hospital, Victoria, Australia for kindly providing HSV-infected Vero cell line; Ms.Nenes Prastiwi for assistance in preparing the manuscript.

\section{REFERENCES}

1. Dharma AP. Indonesian Medicinal Plants. Jakarta. Balai Pustaka $1987: 160-1$.

2. Syamsuhidayat SS, Hutapea JR. Inventaris Tanaman Obat Indonesia. Dep-Kes RI. Badan Penelitian dan Pengembangan Kesehatan $1991: 446-7$. 
3. Balows A, Hausler WJ, Herman KL, et al. Manual of Clinical Microbiology. $5^{\text {th }}$ ed. Washington DC. American Society for Microbiology 1991 : 1184-90.

4. Crumpacker CS, Schnipper LE, Marlowe SI, et al. Resistance to Antiviral Drugs of Herpes Simplex Virus Isolated from A Patient Treated with Acyclovir. N Engl J Med 1982;306:343-6.

5. Whitley RJ, Gnann JW. Acyclovir: A decade later. N Engl J Med 1992;327:782-8.

6. Field BN, Knipe DM, Chanock RM, et al. Fields Virology. 2nd ed. New York. Raven Press. 1990:1843-88.
7. Jawetz E, Adelberg EA, Melnick JL, Brook GF. Medical Microbiology. 18th ed. Prentice Hall International Inc. 1989:358-80.

8. Stagno S, Whitley RJ. Current Concept: Herpes Virus Infections of Pregnancy. N Engl J Med 1985;313:1327-9.

9. Praseno, Suparwoto S, Ning Rintiswati. Antiviral Activity of Momordica Charantia: A Preliminary Study on in vitro anti Herpes Simplex Virus Berkala IImu Kedokteran (in press). 